\title{
The Kola Nut: Its Symbolic Significance in Chinua Achebe's Things Fall Apart
}

\author{
Bawa Kammampoal ${ }^{1 *}$, Suuk Laar $^{2}$ \\ ${ }^{1}$ Associate Professor, English Department, Université de Kara, Kara, Togo \\ ${ }^{2}$ Senior Assistant Registrar, Institute for Interdisciplinary Research and Consultancy Services, University for \\ Development Studies, Tamale, Ghana
}

*Corresponding Author: Bawa Kammampoal, Associate Professor, English Department, Université de Kara, Kara, Togo

\begin{abstract}
The family is often considered as a basic social unit. But in Achebe's world, "caring” is the definition of the family which, to him, consists of related people who care about each other.All families need to be nurtured and strengthened from time to time. All social and cultural practices find their justification in the notion of family, either supporting or distorting it.One of these social customs embodied in the kola nut as well as the language used in its blessing before consumption, is depicted in Chinua Achebe's Things Fall Apart to show both its importance and the civility with which the Igbo people conducted their daily routines or affairs from time imemorial. With this novel, he invites mostly people of colour as well as his own people to read his story as something marked by the history of mistreatment, disenfranchisement, and dispossession to mean that race and ethnicity are not erasable marks; rather, they are the most compelling and effective determinants of cultural difference and literary specificity: language carries the idiosyncratic stamp of the individual and the mark of a nation as well. Thus, the Kola-nut ceremony is among the things which the Igbo deemed very important at any formal or informal gatherings and an apology given for its unavailability.This nut, though not very pleasant to the taste, is very much in evidence on many social occasions for it has great cultural value in fulfilling socioreligious functions.It is shared among friends on the one hand as a token of comradeship or goodwill, and on the other it is offered to a visitor as a sign of hospitality.The primary materials used for arguments in this study is Chinua Achebe's Things Fall Apart. Other fictional works of the author, his essays, and interviews have also been used as reference sources. Some critical works on the writings of the novelist by other critics have been used as secondary sources for the collection of data. All these materials have been closely examined from the theory of sociological criticism, new historicism as well as the reader response theory.
\end{abstract}

Keywords: caring, family, cultural difference, the kola-nut ceremony, socio-religious functions

\section{INTRODUCTION}

In 1964William Abraham, the Ghanaian professor of philosophy (as quoted by Chinua Achebe, 1975) exposes one of the props fashioned by Africans to counter racial prejudice, what Jean Paul Sartre called "antiracist racism" in these terms:

Just as African scientists undertake to solve some of the scientific problems of Africa, African historians go into the history of Africa, African political scientists concern themselves with the politics of Africa; why should African literary creators be exempted from the services that they themselves recognize genuine?

It therefore makes sense to paraphrase Chinua Achebe who believes that the writer cannot be excused from the task of "re-education and regeneration"(1975:45) to announce not just that Africans were as good as the next man but are much better. The South African writer Eziekel Mphahlele in his African Image believes that the "writer must be the "sensitive point of his community" . Chinua Achebe in his essays, writes that his novels, mostly the ones set in the past would make him quite satisfied if they teach his readers that their past--with all its imperfections--was not one night of savagery from which the first Europeans acting on God's behalf delivered them.

${ }^{1}$ Quoted by Chinua Achebe, Morning yet on Creation Day, London : HEB, 1975. 
For Kofi Awoonor, the Ghanain poet, novelist and essayist, the "African writer must be a person who has some kind of conception of the society in which he is living and the way he wants the society to go"(1969:31)."Every literature", writes Chinua Achebe,"must seek the things that belong unto its peace, it must, in other words, speak of a particular place, evolve out the necessities of its history, past,and current and the aspirations and destiny of its people" (1975).

Thus, Chinua Achebe's Things Fall Apart operates on the assumption that Africa and other post colonial literature must present a society discussing its experiences with itself, that is, to restore dignity to the past in showing: "That the African did not hear of culture for the first time from Europeans; that their societies were not mindless but frequently had a philosophy of great depth and value and beauty, that they had poetry and above all, they had dignity". Achebe's text dismantles the racial codes of Joseph Conrad's and Joyce Cary's paradigmatic colonial texts presenting Africans as primitive savages and Africa as a jungle by contextualizing these in an alternative discourse (postcolonial one). The novel has been busy with the restoration of humanity to the African and his/her society through the recreation of precolonial social, political and religious institutions. In other words, the novel offers to correct some of the misconceptions advocated by Eurocentric paradigm on Africa and Africans.

In Chinua Achebe's Things fall Apart, the referent text, the kola nut is articulated as a foodstuff of primary importance in the life of his people. Therefore, the whole livelihood of his Igbo community revolves around it; for it offers to play a role of unity, harmony and solidarity. Among the multiple roles it plays in society, it has social, spiritual, ideological and economic functions. Achebe depicts his people using kola nuts to fulfill different societal functions,thereby,testifying that his own social background is the sum total of his history, culture, philosophy and religion.Today, Chinua Achebe is honoured as one of the founding fathers of modern African literature because of the historically receptive and discerning nature of his writings on contemporary Africa.According to him, the novel form in African society should be used by African novelists to highlight the need to transform the harsh social reality and replace it with a new and viable social system which will work toward giving deeper meaning and a sense of purpose to the life of individuals: educating and guiding the masses.In so doing, he believes this will act as an answer to the erosion of human and social values caused by colonialism and its aftermath and help preserve ethics of the African cultural heritage.

For him, the novel as a literary form is a convenient medium in the hands of an author or authoress in his/her endless effort to project his/her ideas in an effective and powerful way with twofold purposes: firstly to highlight topical issues and social contradictions inherent in the society, and secondly,to thereby suggest effective ways and means as well as measures required to cure the social cancer therein. In the process, his works will contribute to the understanding of readers who are foreign to his culture and to truly recognize the social forces that shape and influence people's lives. In his pronouncement, Chinua Achebe thinks that colonial rulers and their cultural influences have cut accross almost every social sphere of life and have for that matter affected, to a greater extent, African heritage as well as its identity.In other words, it has almost wiped away the traditional ways of life forcing them to lead a rootless existence in a cultural and moral vacuum.In many of his essays, Achebe suggests that the novelists should "act as a teacher" and use literature and education as tools to inculcate a sense of dignified identity in a society torn between the dichotomy of modern and traditional world.The ideas of Achebe about the nature and function of fiction in particular, and literature in general, have stired the conscience of many writers and subsequently led to the flowering of many literary genres in Africa.

The kola nut and the accompanying ritual that goes along with it "symbolize" the customs and signs of respect between the leaders of the Igbo tribe in Chinua Achebe's Things Fall Apart. A ritual is a religious or solemn ceremony consisting of a series of actions performed according to a certain order. In Igbo culture as depicted by the novelist, the kola nut is a crucial part of many ceremonies and gatherings, but it appears in the novel primarily as a way of welcoming visitors to one's home. As a symbol, it is used in West Africa by the Igbos of Nigeria to grace social rituals of hospitality such as welcome offerings to guests, sacred offering in religious rites and prayers; and in ancestor veneration.As a mark of respect the kola nut is broken with a knife and then followed immediately by prayers. In the prayer to the forefathers of the Igbo, people are beaconed to come and participate in the eating of the kola nut and to guide and protect them in the mission that brings the people together. After the prayer is said, the kola nut is broken, shared and everybody eats it. This marks the beginning 
of the ceremony. Before any further discussions are carried on on the quintessence of the use of the kola nut in any gatherings in Igboland, there must be a formal kola nut presentation and this stands out as a life-wire in its social life. Ogbukagu (as quoted in Nnamdi-Eruchalu) posits that: "There is no function or ceremony performed in any part of the Igbo land that presentation of kola nuts does not take precedence. Kola nut is to Igbo people what the prayer book stands for in the Christian world'. (251).It is a fact that the blesing of the nut is exclusively done by the old who are known for their mastery of oratory in their effortto either express an act of gratitude or give praise to the AlmightySupreme God, the gods, deities, goddesses as well as the ancestors in a special language. The fact of the matter is that all African-language literatures deploy oral literary devicesfor invocation, invitation, and to express humility and even a worlview. Since the kola nut is deeply embedded in Igbo culture and language, and language and culture inseparable, it goes without saying that the blessing of the kola nut is done in Igbo language.For Dennis Baron,

Language use carries not only the idiosyncratic stamp of the individual but the mark of a nation as well.Consequently, language becomes both a primary vehicle for the transmission of a group culture and a badge of national identification.In addition to its most basic functions of communication, language takes on symbolic value as the emboddiment of a culture.It has come to represent the most potent symbol of group identity and local nationalistic pride(Baron, 29).

To Achebe, community in African literature dominates all aspects of African thought. Undertakings like dancing and worship are communal activities. Even property was held communally before the colonial era and it is the duty of African writers to reinstate that practice.So tradition plays a big part in reinforcing the communal ethic. James Ene Henshaw (1964:64) testifies:

Tradition is sacred.Custom is above all.To question tradition are sacriledge.If men do not respect tradition how can society stand? How can we be proud of our forefathers and pass on our pride to our children? What will happen if you and I were allowed to change our ancient practices as we like? For us tradition is not a passing thing. It is the earth on which we live and the air we breathe? (1964:64)

It has been argued that literature is the use of language to organize human life and the culture which acts as a guide to life.This organised human life through literary art draws on models, codes, principles, and traditions which have been previously established by the tenants of literature as a written form since the novel form of depicting human life and his/ her cultural patterns is an invention of the West.Fundamentally, the production of written literature itself is the result of influence from other art forms of the same genre.

In this case, if we see life in general, and cultures in particular, as a reproduction of the past as postcolonialists contend, then the present cultural modes and behaviours are determiners of human productivity. In many cases, art in general is an inheritance from older generation in all its forms, characteristics or articulations. In fact, the novel form of a story-telling, for example, is from the West and must not be emulated. But writing a novel in the African context compels the writer to conform to a certain number of regulations which are not optional, but rather the very characteristics of the art form chosen. Achebe's example, that of choosing to write a novel to project African values with adapted tools, is frequently hailed as a reception of the art from the West and inspired by Joyce Carrey's Mr Johnson and Joseph Conrad's Heart of Darkness.

This paper offers to highlight the role of kola nuts as articulated in Things Fall Apart and acts like a symbol of unity and strength in all the Igbo'ssocial undertakings by providing them with blessing. Through its presentation, breaking and eating, it delivers a message of peace because its communion is considered much more than a symbol of hospitality and serves as a covenant among the dead and the living.The concept of the kolanut, its symbolism as well as its usefulness show how much an object (fruit) can serve as an offshoot of sociocultural life of a given people and, for that matter, mould their worldview.

\section{DEFINING SYMBOL AND SYMBOLISM}

The Cambridge Advanced Learner's Dictionary has twofold definitions to symbolism. The first one is the use of symbols not only as confined to art and literature but also in films and other fields, and the second as the symbolist movement and as a type of art and literature, which began in the late 
nineteenth century and tried to express ideas or states of mind rather than represent reality, using the power of words and images. A.H. Abrams (1981: 95) in his A Glossary of Literary Terms defines 'symbol' broadly as anything which signifies something else; in this sense all words are symbols. In discussing literature, however, the term symbol is applied only to a word or phrase that signifies an object or event which in turn signifies something, or has a range of reference, beyond itself.

In his Anatomy of Criticism, Northrop Frye, a critic, posits that symbolism is "Any unit of any literary structure that can be isolated for critical attention. A word, a phrase, or an image used with some kind of special reference (which is what a symbol is usually taken to mean) are all symbols when they are distinguishable elements in critical analysis". Throughout all these definitions, we may argue that the definition of "symbolism" has a meeting point although it may appear to have different definitions and connotations. It may be defined as "the use of symbols to represent ideas or qualities, mostly in art and literature as well"as a first meaning and"as an artistic and poetic movement or style using symbolic images and indirect allusions to express mystical ideas, emotions and states of mind" as a second one.

From all these definitions on symbolism, it goes without saying that a "Symbol is something such as an idea, object, a conventional or nonconventional that is used to represent something else".It is a representation of ideas by something else; a person, place, object or idea that stands for something beyond itself. In symbolism, the object, thing, place or person mentioned stands for, pointsto or shares something in common with another thing, idea or reality, which is over and beyond it.Symbols replace long explanations and they evoke or suggest feelings as well as emotions and appeal to our imagination.Most of the time they enact meaning and have much to do with the theme of a play, poem and a novel.Some symbols are, however, not universal and comes only from the writer's imagination or mind.

Most writers invent some symbols whose meaning is revealed in their literary production.In many cases, such symbols are not easy to find; the reader has to read between the lines to get hints or connection. In literary works, it is not easy to find symbols; but the reader can try to find out if the work is oprerating in a symbolic way. For instance, when an object or an event, or setting is used as a symbol, the writer lays much emphasis on it and it reappears over and over again throughout the story for a symbol is often visual and stands for something essential; different from itself.In fact, despite widely recognized symbols, it is worth noting that in English literature the use of "symbolism"is very important to the overall bearing of literary works produced.Thus the four seasons suggest different ideas; springmeans "a period of new life, energy as well as hope; summermeans a period of "joy and care free living"; autumn, a period of "maturity and fulfillment" and;winter, a period of "old age and death".

In fiction, symbols are not generally abstract terms like "love" or "truth"; but are likely to be perceptible objects or worded descriptions that cause us to imagine them. Most novels have two layers of meaning.The first layer is in the literal plot, and the second layer is in a symbolic layer in which images and objects represent abstract ideas and feelings. Since the beginning of the literary genre, novelists of the 19th century created symbolic patterns of imagery.As an example some famous symbolic works are Nathaniel Hawthorne's The Scarlet Letter (1850), F. Scott Fitzgerald's The Great Gatsby (1925), James Joyce's A Portrait of the Artist as a Young Man (1916), Herman Melville's Moby Dick (1851), and Joseph Conrad's Heart of Darkness (1902) which, later on, deeply influenced Chinua Achebe, the writer of our referent text. For instance, the works of Nathaniel Hawthorne, in all its articulations, explores to a greater extent, the darker side of the human nature; especially, the themes of guilt and the efforts of reconciliation.One famous example of "symbolism" is Nathaniel Hawthorne's novel The Scarlet Letter. This novel gives a glance about the norms and behaviours of 17th century American puritan society.The main conflicts and problems are about the female protagonist, Hester Prynne gives birth to a baby out of wedlock, and refuses to confess who the father of her baby is. As a punishment to her adultery, she wears a scarlet letter " $A$ " that "symbolizes" her adulterous act.Other great use of "symbolism" is F.Scott Fitzgerald's The Great Gatsby (1925). In this novel, huge pair bespectacled eyes stare across a wilderness of ash heaps from a billboard advertising the services of an oculist.Repeatedly entering into the story, the advertisement comes to mean more than simply the availability of eye examinations. Fitzgerald features a character which he likens to the eyes of God; he hints that some sad compassionate spirit is brooding as it watches the passing procession of humanity.Such an object is a symbol; and in literature, it is athing that suggests more 
than its literal meaning. Symbols generally do not "stand for" any meaning, not for anything absolutely definite; they point, they hint, or, as Henry James put it, they cast long shadows.Herman Melville's Moby Dick is a case in point.In this novel, the great whale of the books title apparently means more than the literal dictionary definition meaning of an aquatic mamal.He also suggests more than the devil, to whom some of the characters liken him.The great whale, as the story unfolds, comes to imply amplitude of meanings: among them the forces of nature and the whole created universe" (Kenedy, 1995:236). This indefinite multiplicity of meanings is characteristic of a symbolic story and distinguishes it from allegory, a story in which persons, places, and things form a system of clearly labeled equivalents.In a simple allegory, characters and other ingredients often stand for other definitive meanings, which are found in some biblical parables: "The kingdom of heaven is like a man who sowed good seed inhis field" (Matthew 13:24-30).George Orwell's Animal Farm is a long fable. In this, barnyard animals stand for human victims and totalitarian victims.

Ethics and responsibility are examined through the fiction of Chinua Achebe. In this fictional work, all the characters show an ambiguous taste for living in the community. Interestingly, the novelist in his attempt to restore the past, has in mind cultural and social stakes as regards the aesthetics of the novel.Thus his aesthetic prowess relies on his ability to use the title of the novel, character and characterization, dialogue, and plot in such a way that they act on the surface of the novel to move the narrative along; but symbolism works beneath to link the story's external action to the theme and subject matter. This is exactly what shows in Things Fall Apart. Earlier in the narration of the fiction, symbolism is produced through allegory and gives a relationship between the literal event and its allegorical counterpart correspondence. Allegory is certainly the simplest way of adding more details to a theme. However, it limits the ability of understanding.Thus those works of literature in which elements of mystery exist best illustrate this. Likewise, these works often lend themselves to a variety of interpretations. The next higher level to allegory can be called symbolism. At this level, there is still a form of correspondence, and yet, it is not so one-to-one because allegory operates very consciously while symbolism operates unconsciously. William Shakespeare's Hamlet is a case in point. In this novel, we notice that Hamlet, the protagonist, is fascinated with actors and acting, but the intelligent reader observes that this is so because the protagonist's entire life has become unreal; he is being haunted by the ghost of his own father who was murdered by Hamlet's uncle with whom his mother had married.Thus, the motif of the actor in this context is the "symbol" for the unreality of Hamlet's miserable life. Generally speaking, the difference between imagery and symbolism is obvious because the purpose of imagery is not to incorporate meaning but to create the sense of real experience by stimulating the senses of the reader. Nonetheless, an image may also serve as a symbol if it has special meaning and represents another idea to the reader or to the character itself.

As a matter of fact, African literature was basically oral until the 20th century. The oral tradition containing proverbs, myths, and poetry has influenced the modern written African literature. Almost all the African contemporary writers mix elements from the oral tradition or literature to their fiction because of their oral origins. Creative writers such as Chinua Achebe, Ngugi wa Thiong'o, Ama Ata Aidoo, to mention just a few, came from a people who told stories. Although Africa has had a lasting relative tradition of poetry and drama, the novel is today the dominant literary genre on the continent and has had a powerful impact on African societies. In prose, the folktale is the most important feature of the African literature, and the characters of these stories are animals, trickster hero, in the form of a tortoise, a rabbit, or a spider depending on the setting of the story. In Decolonising the Mind, Ngugi wa Thiong'o explains that animals are the most popular beings in the African societies where the story is set; they have a "symbolic" function and representation of human values in the stories, i.e. personification. The folktales and fables are not the only didactic source in the traditional African societies, but there are the mythical tales like the religious tales that give a history and worldview of a given society. In short, the novel has today achieved the feature of a cultural significance that was once the concern of the oral narrative only.

Since the colonial period, African culture has constantly changed.Thus the contemporary African culture has become a mixture of both traditional and alien elements.Tradition has undergone significant upheavals in terms of religion, social structure, language, values and worldview. African writers believe that their identity is in crisis, and there is a need to write back and to preserve the authentic cultures especially those which are at least in practice; in other words those who withstood colonial intrusion.Since the past, African societies have restored to and preserved their identity and 
history through the arts by using symbols, animal symbols that represent the nature of man, in forms of arts, myths, rituals, language, and names.In African literature, "symbolism", notesN.K. Dzobo, is "the main feature assymbols are sources of insights into African orientations to life" (quoted by Andrew Ifeanyi). When after about a century from the symbolist movement, Chinua Achebe wrote his novel Things Fall Apart itwas considered as a model to the identity of the African literature because it has oral narrative strategies as basis.Today in many academic fields, Chinua Achebe's Things Fall Apart, though a fictional work, is being used in nonliterary disciplines such as history, humanities, natural sciences, anthropology since it records and symbolizes the many events during the colonial period besides the behaviours and way of life of the Igbo people before colonialism.For him, the novel responds to his adequate revolution:

"help my society regain belief in itself and put away the complexes of years of denigration and self abasement.And it is essentially a question of education, in the best sense of the word.Here I think my aims and the deepest aspirations of my society meet. For no thinking African can escape the pain of the wound in our soul" (1975:44)

Thus, this provides the novel with materials that allow its being studied from many perspecives or angles. I have chosen one angle which is to show how human relatioships were monitored or managed and how a fruit can serve as a symbol in bringing a people closer or together and thereby foster relationships. Throughout the novel,the "kola nut" is ready to be eaten after it has been used to ask for blessings and hallowed as a vehicle for showering blessings on recipients and shows that the symbolic significance of the kola nut is spelt out.Since "symbolism" is a basic feature in African literature which includes the oral tradition, Chinua Achebe has givenmuch importance to the function of names, colours, rituals, animals, spirits, gods, stories, and even gestures and events in his novel Things Fall Apart. First of all, the title, which is taken from William Butler Yeats's poem The Second Coming because of the relevance of the subject matter: Yeats's poem resembles that of Chinua Achebe's novel and constitutes in itself a suitable title to his novel because the society of his Ibo people and their way of life and tradition are faltering. Throughout the novel, Chinua Achebe uses symbols to suggest this by using Igbo words and phrases, proverbs, storytelling, myths and other elements of oral tradition in order to record and preserve the Igbo oral tradition.This latter contributes in giving African literature its identity. The use of special language has another meaning. The novel was published just before the independence of Nigeria in 1960 and, for that matter, comes to destroy the western conception of the African and his civilisation but restores as well African cultural values and history. As Killam suggests the novel is a:

"thorough in its delineation of the total cultural pattern of nineteeth-century Ibo life...the strengh of the book partly lies in in its naturalistic description and its detailed presentation and analysis of the day by day and hour by hour issues of social living.But while he works at the level of ideas, Achebe also works at the level of symbols- that is, the level of concepts which have significance and validity on the level of different from that of logical thought" (1969:14)

Things fall apart, which is not written from the people's point of view but from Achebe's, is a work of a twentieth century Igboman, a decolonised writer, acts as a vision of what life was in Igboland between 1850 and 1900.Chinua Achebe makes a serious attempt to capture realistiscally the strains and tensions of the experiences of Igbo people under the impact of colonialism with the idea of the wide gulf which exists between present day society and that of the Igbo villagers over sixty years ago.Umuofia is an organic unity which has witnessed significant upheavals in the texture and structure of the Ibo society.This paper offers to indicate the deftness and certainty with which Chinua Achebe establishes the characters of Unoka and Okoye,Okonkwo and Nwakibie,Okonkwo and Ezeani, the priest of Ani, Okonkwo and Obirieka, and their social interactions as viable human beings who show great sense of belonging in a relation controlled by the kola nut. Umuofia where the novel is set is a place where people live, a community, a center of cooperation and conflicting men and women, which achieves an identity of its own and unified by an Igbo consciousness and achieves a rich ambiguity which refers ultimately to Umuofia and the nine villages as well as the whole Igboland.

${ }^{2}$ Quoted by Andrew Ifeanyi Isiguzo, African Culture and Symbolism: A Rediscovery of the Seam of a Fragmented Identity, 
The kola nut is an indispensable fruit in Iboland as far as formal and informal social gatherings are concerned. Before any further discussions are carried on on any issue, there must be a formal kola nut presentation and this stands out as a life-wire in its social life. Throughout Things Fall Apart, we find expressions that give a symbolic function to the kola nut. For instance, Okoye a character in the opening pages of the novel says, "who brings kola brings life". This connotes prosperity and continuity. When the kola was given to Unoka he prayed to the ancestors for blessings. Afterwards, he broke the kola and threw one of the lobes on the ground for the ancestors.The acts of presenting; breaking as well as the sharing of kola nut symbolizes unity.It should bealso note that, sharing the kola between the Ibos represents love, peace, greeting, kindness and gratitude.This is illustrated by Okonkwo's address to his uncles: "I [Okonkwo] beg you [kinsmen] to accept this little kola," he said. "It is not to pay you back for all you did for me in these seven years. A child cannot pay for its mother's milk. I have only called you together because it is good for kinsmen to meet".

\section{The Kola NuT ${ }^{3}$ IN IGBo COSMOLOGY}

The Kola nut acts like a symbol of unity and strength by providing the Igbos with a blessing by cutting across all social spheres and undertakings.Through its presentation, breaking and eating, it goes to the heart of African traditional values and delivers a message of peace for its communion is much more than a symbol of hospitality and serves as a covenant among the dead and the living. It is a distinct ritual act which goes hand in hand with the pouring of libation and gives some idea of the complexity of and relevance of mere cultural rites. The concept of the kolanut, its symbolism and usefulness show how much a fruit can serve as the offshoot of sociocultural life of a given people and for that matter mold their worldview. The kola nut is an important fruit in the African community; mostly in Nigeria, West Africa ${ }^{4}$.It is commonly eaten. In the core of African community it not only serves as an economic asset, but it also serves as a high cultural value by fulfilling socio-religious functions. As far as societal functions are concerned, while the act of offering kola nut makes it a remarkable symbol of hospitality, and for that matter friendship, the act of breaking it is a significant ritual enactment. Among Chinua Achebe's people, presenting, offering and breaking it is a solemn ritual which reflects the spiritual and social realities of their traditions and customs.

The drama during which a whole community is involved symbolizes and fosters their mores and relationships. Broadly speaking, a symbol is anything which signifies something else. In this sense, all words may appear to be symbols. In literature, however, the term symbol is applied only to a word or phrase that signifies an object or event, which in turn, signifies something, or has a range of reference, beyond itself.Conventionally or publicly, some symbols like "the red" and "the blue" are terms that signify symbolic objects of which the further significance is to determinate within a particular culture.Obviously, "the cross" as well as "the good shepherd", brings us back to the memory of EuroChristian culture while the drawing of the crescent and the moon strategically placed in its hollow centre reminds us of another creed, Islam. In general when a symbol is used in literature, the purpose is to give it a meaning which goes beyond the physical representation merely. In other words, symbols

\footnotetext{
${ }^{3}$ The Kola nut is a native to West Africa although it has found its way to so many other countries. The kola nut is a reddish or yellowish small content of the pod of a tree called kola nut tree. The tree does not grow to a great height. It is caffeine-ladden and often prevents the eater from sleeping and gives vitality when chewed. The kola tree is an evergreen tree whose origin is tropical Africa. It produces woody fruits, in the form of pods, inside which are the nuts. The genus cola, among which we are interested in is called cola acuminata and belongs to the sterculiaceae family. Cola acuminata could be dark red or cream-coloured. Kola nuts have high caffeine content and are sometimes used in the production of soft drinks.

${ }^{4}$ In West Africa, generally, the nuts of some special species have economic value, as many people trade on them. They are also eaten as part of diet. Although kola is neither the biggest nor the sweetest fruit in Iboland, the nuts have tremendous cultural significance. In fact, kola nut is ritualized among the Igbo people of Nigeria and is specifically men's affair. In traditional Igbo setting where the man lives in his "obi" while the wives (and the children) live in their huts, kola nut is served at the "obi". Now that many couples live under the same roof the woman assembles kola nuts, and hands the saucer over to the husband to present to their guest. Where the woman is a widow, she may invite any male relation of her late husband to come and present kola nut to her guest. In many West African cultures too, it is chewed and it is believed to restore vitality and ease hunger pangs. Kola nuts are an important part of the traditional spiritual practice of many cultures and religion in West Africa, particularly Nigeria where the novel is set.Kola nuts are used as a religious object and sacred offering during prayers, ancestor veneration, and significant life events, such as naming ceremonies, weddings, and funerals.
} 
are used to convey messages. The kola nut is a small seed which comes from a plant that grows as a big tree in the tropical forests of West Africa andwhose taste is very bitter, caffeine-laden; but is endowed with a strange property. When chewed it prevents one from sleeping and gives endurance.InChinua Achebe's community the kola has an important role to play. The Igbo people honour and love it because of its sociocultural significance. In West Africa where it is cultivated on a large scale, its value varies from one community to the other. For instance, in predominantly Muslim Hausa as well as Yoruba communities Kola nut is offered as a symbol of hospitality; but without elaborate ceremonies like the Igbo.

In his fictional works, Achebe shows that the kola nut is used as a solemn ritual. The actsof presenting, blessing, breaking, and distribution of the kola nut are much more a solemn.As an important social and cultural symbol, kola nut is the backbone of the Igbo's society and worldview. It serves as a social and ritual bond between the living and the dead and is, in this case, considered as a ceremonial covenant of hosts and guests with benevolent ancestral spirits and deities.In traditional Igbo society, the use of the kola nut has cut across all social spheres with manifold purposes: it is not only used to offer prayers to the gods but also to offer them as rituals, to usher a new day, to welcome guests, to take oaths, and through this commune with the spirit world which people believe has the ultimate control over every sphere of their life's span and space.This analysis will focus on the kola nut and its multiple uses; its social, spiritual and economic functions in the Igbo cosmology as articulated by the novelist to show that his culture is worth considering.

\section{The Societal Function of the Kola nut in Things Fall Apart}

The Kola nut is one of the most important things in Igbo land. Even though it is called kola nut, the nut is actually a large seed kernel. These seeds must be opened by a man and with a knife. In There Was A Country, written and published by Chinua Achebe in 2012, the novelist talks about 'the kola nut incident' as a violating of a male preserve .In fact, Achebe's mother once pulled down a small kola nut branch from a tree in her compound and picked a ripe fruit. This taboo about picking kola nuts raised much concern in the community as traditionally no one was allowed to pick them from the tree unless they are ripen, fall, and then to be collected from the ground, and by men-not by women.The kola nut was a sacred fruit and had very distinct and distinguished role to play in Igbo life and culture (2012: 10).

The symbolic process involves three main steps: the presenting of the kola, its breaking anddistribution. As far as the breaking of a nut is concerned, the responsibility falls on either the oldest or youngest male.Once the kola nut is broken;its pieces are distributed to everyone starting with the eldest, by the youngest among them. When kola nut is present, the host hands it to the oldest man among his guests.The oldest man then shows it to everyone present and then passes it around and when each of them records his approval by touching the nut, greetings and prayers are said to God Almighty, the gods as well as the ancestors.Prayers are usually for life, happiness, good health, children, prosperity and good harvests. Kola nuts also aid as a natural caffeine and a stimulant. In many cases people use these nuts as a stimulant, anti-depressant, sea sickness and as a diuretic. Not only does this nut help cure hunger and fatigue, but it also plays a big part for the social life of this tribe.

In this paper I offer to analyse the ceremonial and symbolic significance of the kola nut in Chinua Achebe's Things Fall Apart as it is used multipurposefully in rituals.A ritual is a religious or solemn ceremony consisting of a series of actions performed according to a certain order. In Igbo culture as articulated in the novel, the kola nut plays a crucial part in many ceremonies and gatherings, but it appears in the novel primarily as a way of welcoming visitors to one's home.In Igbo culture, the kola nut is a symbolic ritual of respect, and is offered by hosts to make guests feel welcome. In Achebe's world the kola nut is ascribed many rolesright from day break to dawn. According to Geraldine I. Nnamdi-Eruchalu, the numerous purposes the kola nut serves in Igbo land are as follows: it is used to welcome a new day, i.e. to usher in a new day, day break, welcome guests during meetings or public gatherings, divination, sacrifices, oath taking, and idol worshipping. The kola nut and the accompanying ritual that goes along with it symbolizes the customs and signs of respect between the leaders of the Igbo tribe.This is legion in Chinua Achebe's Things Fall Apart.

In Chapter 1 of Achebe's text, we are introduced to the use of the kola nut which, to him, is a very significant object in the Ibo culture. This is found in an exchange between Unoka, Okonkwo's 
father andOkowe: as "He who brings kola brings life" (6).In this community, kola nuts, as well as palm-wine, are constantly mentioned, especially during solemn ceremonies, to lay emphasis on the quintessence of traditional hospitality among the Igbo people.For instance, when Okoye came to see Unoka, to collect a debt of "two hundred cowries" he ows him, they did not start talking immediately about it. Instead, Unoka the host prsented to his guest kola nut as a symbol of hospitality. After the ritual, they started arguing about who could break the kola nut, until eventually Unoka "accepted the honour of breaking the kola". As the custom goes, Okoye "took a lump of chalk, drew some lines on the floor and then painted his big toe" (6). As he broke the nut, "Unoka prayed to their ancestors for life and health, and for protection against their enemies" (6).This is an omen that blessings will shower on them.

This honour included by Chinua Achebe right from the beginning of the novel wants the reader to understand that when kola nuts are introduced, itmeans or signifies how honourable and respectable it is, for a person to break a kola nut. For generations, breaking a kola nut is considered a highly spiritual process. After this short "ceremony", they talked about many things nature offers them. They talked about the next ancestral feast, the heavy rains which were drowning the yams, and about the impending war with the Mbaino village.Immediately after this ritual of breaking and eating the kola, Okoye told him why he came to see him. Through this simple ceremony the reader can see and understand that the kola nut is a very significant object and plays an important role in the Ibo culture. For the novelist, it is also a symbol of respect to the guest and must be offered on a regular basis.Respect is an important characteristic between Okoye's family and that of Unoka. Both families accept that they each have their own personalities, qualities and interests.Everyone plays an important role in family ties. Though Unoka is known for his laziness and Okoye as a hardworker, they live in mutual respect.Unoka has no title to date; but Okoye is vying for the Idemili title, the third highest in the land, and need to gather resources.Unoka was unable to pay the debt. Very deceived at the answer given to him, by Unoka, "Okoye rolled his goat skin and departed" calmly. (8). In societies like this, when there is a conflict between family members, it is resolved in a positive and healthy manner.The novelist introduces the reader tofamily members, who acknowledge each other's accomplishments and shows appreciation for other members. Unoka owes a lot of money to almost every member of the society and tells Okoye blatantly that he intends to pay "big debts first" (8). This instance intends to show that although every family is different; they have characteristics that they share and from there cements the quality of the relationship in the community which seems to be more important than family configuration.

The Igbos are a people who have profound respect for the customs and traditions of their tribe.They live interdependently. One of those social customs is embodied, as was said earlier, in a fruit called the kola nut, and an instance in chapter 3 of the novel, depicts the importance of the kola nut and how it enables the tribe members to conduct their affairs in society.Okonkwo's visit to the wealthy Nwakibie to ask for yam seed to start his own business, as he had inherited nothing from his father Unoka, is expressed by proverbial materials.He took with him a pot of palm wine and a cock.On his arrival, two elderly neighbours were sent for and the oldman's two sons were present with him in his obi.Nwakibie presented "a kola nut and an alligator pepper, which were passed round for all to see and returned to him". He broke the nut saying:

"We shall live.We pray for life, children, a good harvest and happiness.You will have what is good for you and I will have what is good for me. Let the kite perch, let the eagle perch too. If one says no to the other, let his wing break" (1994:19).

After the kola nut had been eaten, Okonkwo brought his palm wine. In an exchange with the wealthy farmer on the issue of borrowing yam seed, Okonkwo uses a proverb to sustain his love for hard work and promises to pay back by saying that : "The lizard that jumped from high iroko tree to the ground said he would praise himself if no one else did".(1994:21.) To explain why he has been stingy with his yams for the youth refuse to care for the yams and leave to be chocked by weeds, he says: "Eneke the bird says that since men have learned to shoot without missing, he has learnt to fly without perching" (1994:21).And he then concludes convincingly saying that: "as our fathers said, you can tell a ripe corn by its look.I shall give you twice four hundred yams."'(1994:21). The reference to and incorporation of "much proverbial materials couched in traditional verbal formulae with a sense of appropriateness" (Killam, 1969:19) on this particular page and on many others help the author to comment on the environment and subsequently use it to define on the one hand, the moral and ethical 
principles on which his Igbo society is based and on the other to symbolise character and theme.This shows in the behaviour of both Okowe and Nwakibie.They are presented to the reader as altruists who are responding to the one of the cardinal aspects of traditional society: lacking greed and gregariousness; always willing to help the weaker.They live according to the important dictum of communal life "live and let live" nature; a type of society in which nobody goes out to deliberately frustrate another.

It is worth noting that the customs regulating social relations emphasize the people's common interests and culture thereby, diffusing possible tension. The novel is full with instances which sustain these ideas.The neighbours in need further ease the situations by introducing the subject of debt or borrowing through a series of Igbo proverbs, thus making use of a shared oral tradition, as Okoye does when asking for his debt and as Okonkwo does when he asks Nwakibie for some seed yams.For Achebe, "proverbs are the palm-oil with which words are eaten" (1994:6). In Achebe's philosophy, he makes an effort to illustrate his thought with a lot of African proverbs which are based on agrarian occupation with moral-oriented views towards the best possible individual well-being and community harmony.To my mind, Achebe's carefully selected proverbs are wise sayings used adequately to give credence and intelligent support to assertions during discussions. In so doing, Achebe the "father of modern African literature" deals with all the aspects of traditional life and conveys precise moral lessons, warnings and advice accordingly. In Africa, proverbs make a greater impact on the mind than ordinary words. Through his emphasis on the harmony and complexity of the Igbo community,Achebe vehemently contradicts the stereotypical, European representations of Africans as savages

In Achebe's context, a healthy family relationship provides members with a genuine support, encouragement and the empathy they need to progress.Hence, they engage in positive and meaningful communication for a harmonious society.All family members in Achebe's world are bound to listen and to aptly care about what others say as far as topical issues are concerned.In healthy families like the ones depicted in Things Fall Apart, as the novelist insinuates, communication is such that that all members of the community are able to share their own feelings, goals, accomplishments and experiences with others.As was discussed earlier, it now dawns on the reader that there is an entire social system of etiquette and routine that goes along with the breaking and eating a kola nut. The privilege of breaking it is a great honour and a sign of respect in the Igbo community. The whole thing is a sacred communion that happens before matters of business can be approached.This respect for the custom translates into respect for one another. The saying'He who brings kola brings life' can be translated as the fulfillment of the kola ritual which, to a greater extent, sustains the Ibo way of life. In another instance, Obierika visits Okokwo when he was in exile for having inadvertently killed a countryman.

On Obierika's arrival, he was presented the kola nut. Okonkwo "got up painfully, went into an inner room and came back with a kola nut." He presented it to them and when they had seen it and thanked him, he broke the kola nut."(137).After this, a pot of palm wine was brought and they began to drink while discussing issues pertaining thestability of their region.It is through this that Okonkwo got to know that, "Abame has been wiped out" by the white men after having killed their fellow whiteman.In the process, Obierika who disclosed the sad news to him told him that the two bags they were carrying were full of cowries earned through the sale of Okonkwo's yams. When Ofoedu visited Obierika, he was offered a lobe of kola nut which he and Okokwo have broken and eaten in his obi as a symbol of hospitality.It was there that Obierika informed him that his daughter, Akuebue,will soon get married. On the dday, when Akuebue's suitor came for the ceremony, Obirieka sent for Akuebue's mother to bring them Kola nut. But it was Akuebe herself who brought the kola nut. It is worth recalling that in this community, the kola nut is one of the most important items to be included or to be used in contracting marriages.During the ceremony, it is presented by both parties: the bride and the groom. When a man, as in this case, comes to ask a girl's hand in marriage, he comes with a specified number of kola nuts; but before the groom's family brings their kola nut out, the bride's family would have welcomed them with theirs.

When Okonkwo has purged his banishment of seven years, he organized a big feast to thank his mother's people for having helped him in several ways or for having made his sojourn with them comfortable. On the day of the feast he called his uncle, Uchendu and gave him the kola nut to break.Indeed, he broke the kola nut and prayed to the ancestors asking for health and children in the terms: 
"we do not ask for wealth because he that has health and children will also have wealth. We do not pray to have more money but to have more kinsmen. We are better than animals because we have kinsmen.an animal rubs its itching flank against a tree, a man asks his kinsman to scratch him"(165).

After the speech which his uncle delivered, he then "broke the kola nut and threw one of the lobes on the ground for the ancestors."As the broken kola nuts were passed round, Okonkwo's family began to bring out the food and the pots of palm wine.There was so much food and drink that many kinsmen whistled in surprise. When all was laid out Okonkwo rose to speak: "I beg you to accept this little Kola", he said.

In chapter four of the same novel, after Okonkwo beats his wife during the Peace Week, the priest of Ezeani refuses to share hospitality with him and boldly tells Okonkwo: "Take away your kola nut. I shall not eat in the house of a man who has no respect for our gods and ancestors." Obviously, Okonkwo's wicked actions have compromised his position in the tribe and he is no longer worthy of the honour conferred by the kola nut.This adds to the significance of the kola nut as being more than just a well-known social custom; instead it is symbolic of the worth of all men until they prove themselves unworthy.This episode which features the kola nut depicts these two Igbo men as civilized beings rather than as savages living in a civilized world in which the host shows respect for guest as had been said by Conrad. The Igbo believe that "[h]e who brings kola brings life". That philosophy is embodied in the actions of the priest, mentioned above. If kola brings life, it should not be shared by or given to those who do not promote life. Okonkwo is violent in many ways, and in this tribe, what one man does, affects everyone. He is not worthy of the kola. Achebe achieves his goal of showing the honour, personality and civility of the Igbos through the kola nut.

The Week of Peace is annually celebrated in the Igbo culture as a means of expressing gratitude and humility, as well as teaching people to be peaceful.It was originally created to pay tribute to Ani, who is the Earth mother goddess,to the earth goddess, Ani. In Things Fall Apart, many individual events and acts are discussed as having far-reaching significance. In fact, it should be emphasized that most creeds have different types of holidays or events that they observe or celebrate over the course of each year. For instance, in Euro-Christian religion, with events like Christmas and Easter.The Igbo society is no exception.One of the events they observe, as described by Chinua Achebe in Things Fall Apart, is the week of peace.The week of peace is the week right before the yams are planted every year. During this week, no one is allowed to use a harsh word or abuse a fellow citizen. Everyone is supposed to be completely peaceful with everyone else. This is done to honour the earth goddess, so that she'll bless the crops and the village will have a good harvest. Since Things Fall Apart is a work of art, the week of peace has more far-reaching significance than simply as a religious observance. The significance comes from the main character, Okonkwo, and his detrimental actions.

One night during the week of peace, Okonkwo is waiting for his youngest wife, Ojiugo, to bring him dinner. When she doesn't come, he goes to find out why. He discovers that she went to a neighbour's hut to get her hair plaited, and hasn't come back yet. Not only does she not have Okonkwo's dinner ready, as he expects her to have, but she didn't get her children dinner either, and one of the other wives had to do it. This makes Okonkwo extremely angry, and 'when she returned he beat her very heavily. In his anger he had forgotten that it was the week of peace. In his tribe, this is a huge offense to the earth goddess.In Igbo cosmology, this goddess is a powerful one: while acting as the guardian of the people and place and as the goddess of fertility, she can also be fiercely destructive as well as vengeful. Immediately after the offense, a local priest pays him a visit and then, admonishes him, saying, "The evil you have done can ruin the whole clan. The earth goddess whom you have insulted may refuse to give us her increase, and we shall all perish." For this offense, Okonkwo is commanded to make amends: he has to take a goat, a hen, some cloth, and a hundred cowries to the earth goddess' temple.This instance represents wider patterns in the story.One is the idea of the individual ethic versus the communal ethic. Basically, the village as a whole is far more important than any individual, even one who is as important as Okonkwo.His actions during the week of peace would not only affect the yieldance of his crops, but also that of the entire village.The fact of the matter remains that whatever far-reaching effects an individual's actions can cause, they can be extended to the whole village.

Elechi Amadi (1966: 6-7 ) discusses the same issue in his novel The Concubine where divination is the subject matter. In the Igbo community where the novel is set, a man has the right to visit a diviner 
in order to enquire something of importance from the oracles and ancestors as far as his lifespan is concerned. For instance, when someone is mysteriously ill or dies unexpectedly or when unsual things befall the family or the compound or better when someone wants to get married or to marry his daughter a deviner is consulted with kola nut, wine, gin and the blood of fowls are offered to the 'gods'. The novelist vividly captures this when : 'Nwokekoro [the soothsayer] went into the temple and placed some kola nuts in front of the two carved figures clothed in blood and feathers (16-17).In another instance, when a cobra spat in Madume's eyes, Anyika, another dibia was called upon. The narrator aptly puts it in this way :

'Let me have some kola nuts and gin, 'Anyika said. They were brought. Anyika broke the nuts, cut them into pieces and threw them outside. He poured out some gin as libation and muttered as each drop reached the ground....then he brought out his divination cowries that made name resound from the waterside village of Omokachi to the far, far lands of the Wakanchis.... (6-7)

The Igbo regard these idols as supernatural beings that must be revered with the presentation of kola nuts. It is only when the beings have been saluted that requests, appeals, and prayers can be made to them or else their wish will not materialise.

In chapter 4, the narrator tells us that this sacred week comes at the "end of the carefree season between harvest and planting", and is a religious festival which is intensely important in the tribe's view of the world. Ezeani reminds Okonkwo of the sacredness of the week of peaceas follows.

"You know as well as I do that our forefathers ordained that before we plant any crops in the earth we should observe a week in which a man does not say a harsh word to his neighbour. We live in peace with our fellows to honour our great goddess of the earth without whose blessing our crops will not grow."

Therefore, by breaking the rules of the Week of Peace, Okonkwo will have angered the earth goddess, who in turn, might not give them a good harvest, therefore threatening the whole tribe. The Week of Peace is therefore an important festival for the Igbo tribe as it comes between the end of the harvest and the beginning of the planting and it is a time of peace to solicit the earth goddess's blessing on next year's harvest. It also means unification for the clan and works towards appeasement for the gods in control over their crops. During this week, people spent time meditating and with their families so as to restore their inner peace.This annual event is important in the Ibo culture and is followed by the sowing season for all the crops. Normally people would visit their neighbours and drink palm wine together, however this year they all talk about Okonkwo's actions. The week of peace also represents balance, an important theme throughout the novel. By breaking the sacred peace, Okonkwo upsets the balance in the tribe, which would result in failed crops. He then has to restore the balance by making amends with the earth goddess.

In Igbo cosmology, it is a known fact that during this period, in order to have a good, clean crop, the spirit must first be cleansed. No marital relations, physical abuse, or hurtful language is allowed during this week.Spiritual purity is held very dear in Ibo culture.But Okonkwo's behaviour during this week, and his eventual punishment, which he accepts with dignity, demonstrates that Umofia is not full of savages living in a jungle. Here Achebe wants to show that when constructive criticisms are made of a given person, love and affection are made clear by the use of positive words for comfort. Most of the members of Umuofia community hold the family as a top priority and consider the impact on relatives before making important decisions. The Igbo family members live in interdependence and are always there for each other in times of crisis. Therefore, all the members do not feel they are on their own or do not have anybody they can count or rely on.They spend time doing enjoyable activities together. Some of these activities become family traditions, such as sharing meals together, having family outings every weekend or playing sport together.

The fact of the matter remains that in British, French or American culture or any other, there are lots of little customary rituals that symbolize hospitality, and make guests feel welcome, comfortable and respected. Colonisation and its aftermaths have shown that if your guest is a stranger, the host might first shake the hands of the guests and then invite them to come in. Sometimes the host may take their coat and, then, try to offer them something to eat or drink. If they knew each other, a "hug" might be given to express close friendship. Likewise in Achebe's Igbo culture, the kola nut and its 
accompanying ritual plays similar role. It symbolizes much consideration and respect between the leaders of the Ibo tribe as featured in Things Fall Apart.A ritual is, most often, a religious or a solemn ceremony consisting of a series of actions performed according to a certain order. In Ibo culture, the kola nut is part and parcel of many ceremonies as well as gatherings. In this novel, the ritual of the kola nut is presented as a way of welcoming visitors to one's home on purpose.

Just like in many other cultures, one offers one's guest something to drink when they visit us as a symbol of hospitality. In Achebe's text, however, the process of breaking kola is more honorable and more spiritual. The host passes a plate of kola nuts to the most senior member of the group at a gathering, who, in turn, passes it to the next senior member and so on until it returns to the host. Once the host regains the plate, he gives one of the nuts to his visitor and says, "When the kola nut reaches home, it will tell where it came from."'This proverb means that the guest will have to show this nut to the people at home as proof of his visit. After this, the oldest man present blesses the nuts by saying, "Whatever good he is looking for, he will find." Then either the host or a selected person to break the nut will do it, followed by people close to him breaking the others. The significance of breaking this nut is that the more pieces it breaks into, the more prosperity and benedition the host and his guests receive. However, if the nut breaks into only two parts; it is a sign that the host has some sort of sinister motives.

Achebe suggests that many things which are true of Umuofia are true throughout the villages of precolonial Nigeria. Umuofia can thus be seen as representative of the tribal societies that have not yet been altered by colonialism, that is, by the exploitative policies and invective actions of imperial powers.WithinThings Fall Apart,this view of life in Umuofia as reflecting larger patterns is shared both by Okonkwo, the novel's protagonist, and by the British District Commissioner. Achebe decides to use events in Umuofia to illustrate his book about the process of colonization.The village of Umuofia is at the heart of the action in Chinua Achebe's fictional work. Umuofia can be seen as a microcosm of Nigerian society, an archetypal village in one word. In this, the novelist takes pain to describe drastically and carefully analyzes the village's rituals and social customs. Religion is a crucial part of Umuofia's communal identity.Spirits, good as well as evil, tied to natureare very significant to Umuofia's religion, as is illustrated by the Evil Forest, and the cave from which the prophetess delivers her sinister pronouncements. Another element of Umuofia's religion is the concept of chi, a personal god or fate which influences an individual's actions. Okonkwo's downfall is a case in point.Things Fall Apartis a novel in which much is implied, rather than stated explicitly.Chinua Achebe's artistic feat lays in his ability of clearly illustrating important themes in the novel, and truths about the society they portray.The novel's title is an epigraph taken from W.B.Yeats's poem which suggests the book's central theme: Faltering.Thus, in Achebe's world,"as things fall apart, Umuofia is the symbolic center that cannot hold".

\section{"Umuofia kwenu!" \\ "Umuofia ya!"}

This ritual exchange calls public gatherings to order in the village of Umuofia, a ceremonial way of uniting the people before decision-making, religious observance, or celebration. Like many of the Ibo phrases featured in the novel, it is not directly translated. But its meaning is clear in context. It is a shout of greeting and affirmation, which is then joyously echoed by all those assembled.The expression encapsulates the great pride that the villagers, particularly Okonkwo, feel in their identity as members of the community of Umuofia.Right from the beginning of the novel, Chinua Achebe tries to "help [his] society regain belief in itself and put away the complexes of the years of denigration and self-abasement" (1975:44). In so doing, he thinks, it is essentially a question of education, in the best sense of the word. He further notes that his aims and deepest aspirations of his society find its justification therein.Achebe's Things Fall Apart prove to a greater extent that Umuofian society is culturally, socially, and politicallywell-organized group with viable societal norms.It is a community which is held together by the same feelings of belonging to the clan or village.This sense of belonging is identified with a belief and a common value that is attached to the same norms, institutions, and material environment.This socialization or sense of belonging is best illustrated in many social gatherings.

Africans are depicted in colonial literature as primitive, speechless, and mindless savages living in dangerous jungles. In this, Achebe interposes Western linguistic forms and literary traditions with 
Igbo words and phrases, legends, proverbs, fables, tales, and other elements of African oral and communal storytelling traditions so as to record and preserve African oral traditions and to subvert the colonialist hegemonic language, literature, and culture. In pre-colonial Africa in general, and particularly in Achebe's Igbo community, oral tradition characterized life because traditional society was basically an oral or agrarian one. Chimamanda Ngozie writes that, "The single story creates stereotypes, and the problem with stereotypes is not that they are untrue, but that they are incomplete. They make one story become the only story." ${ }^{, 5}$ or her, "Stories have been used to dispossess and to malign, but stories can also be used to empower and to humanize.Stories can break the dignity of a people, but stories can also repair that broken dignity."

In an interview in the 1994-95 issue of The Paris Review, Chinua Achebe states that he has become a writer in order to tell his story and that of his own people from his own viewpoint by explaining how dangerous it is for an African, as he was, for not having his own stories through a traditional Ibo proverb: "until the lions have their own historians, the history of the hunt will always glorify the hunter." For Chinua Achebe, this is what happens when complex human beings and situations are reduced to a single narrative; in other words, when Africans during the period of colonisation were depicted by Western hegemonic stories solely as pitiable poor, starving victims with flies on their faces and who have neither history nor civilisation.

\section{CONCLuSiON}

In this paper the kola nut ritual has been discussed as a significant acumen in Chinua Achebe's description of his Igbo society in Things Fall Apart. In this fictional work,the kola nut is depicted as a symbol of hospitality, friendship and respect.It is presented to guests at important meetings, social events such as weddings, funerals, and infant naming ceremonies throughout the novel.Despite its multiple purposes, the kola nut is broken and eaten when a host welcomes a guest into his home, and constitutes for that matter a powerful symbol of mutual respect in the community.Chinua Achebe presents the kola nut as a fruit which has great cultural value, and fulfills crucial socio-cultural functions though it is offered as a mark of hospitality, and considered as an important gesture of friendship and comradeship.In this work, for the true essence of kola as a cultural symbol to be appreciated, the simple act of its presenting, offering and breaking constitutes in itself a serious ritual enactment. Right from the beginning of the novel,the breaking of the kola nut is not only a solemn ritual, but it is also a piece of drama during which a whole community lights up, reflecting their spiritual and social realities, their mores well as relationships.In Achebe's fictional works, it is presented to the reader as an important fruit: right from the first pages of the novel, it is a type of symbolism which attracts the attention of the reader as very significant in the Igbo culture for itis a seed that connotatively brings "real life" to the community or better a seed of life. The value of this fruit is presented throughout his novels so as to emphasize its quintessence towards the Ibo culture.

Fundamentally, the production of written literature itself is the result of influence from other art forms of the same genre. In this case, if we see life in general, and cultures in particular, as a reproduction of the past as post colonialists contend, then the present cultural modes and behaviours are determiners of human productivity.In many cases, art in general is an inheritance from older generation in all its forms, characteristics or articulations.Another important way in which Achebe challenges such stereotypical representations is through his use of language to counter the fact that colonialist Europe tended to perceive Africa as a foil or negation of Western culture and values, imagining Africa to be a primordial land of silence. But the people of Umuofia speak a complex language full of proverbs, literary and rhetorical devices.Achebe's translation of the Igbo language into English retains the cadences, rhythms, and speech patterns of the language without making them sound, as Conrad did, "primitive." The kola nut is part and parcel of the tradition in Nigeria and holds great social significance for many ethnic groups.

\section{REFERENCES}

[1] Achebe, C (1958,1994).Things Fall Apart, New York : Anchor Books Edition, 1994.

[2] Aig Imoukhuede, F (Ed.). (1991). A Hand book of Nigerian Culture. Ikeja: Department of Culture, Federal Ministry of Culture and Social Welfare.

\footnotetext{
${ }^{5}$ Combing humour and cultural perspective, Chimamanda Ngozi Adichie broadens our world on "The danger of a single story 'TED talk, 2009.

${ }^{6}$ Ibid.
} 
[3] Amadi, E. (1966). The Concubine. London : Heinemann Educational Books Ltd.

[4] Basden, G.T. (1983). Among the Ibos of Nigeria. Lagos: University Publishing Co.

[5] Basden, G.T., (1966, 1937). Niger Ibos. London: Frank Cass and Co. Ltd. (161-162).

[6] Cambridge Encyclopedia (2000). (4th ed).Cambridge: Cambridge UniversityPress.

[7] Hutchinson Encyclopedia. (1999).4th edition. Surrey: Helicon Publishing Ltd.

[8] Chidume, C.G., U.S.Ossissioma, S.O. Echem(2015). The Symbolism of Kolanut in Igbo Cosmology: A Re-Examination. In International Journal of Research in Humanities And Social Studies, Vol.2, Issue 8, August.

[9] Isiguzo, A.I., African Culture and Symbolism: A Rediscovery of the Seam of a Fragmented Identity, Retrieved July 21, 2018 from http://www.crvp.org/seminar/05-seminar/Andrew\%20Ifeanyi\%20Isiguzo.htm

[10] Kammampoal, B. (2013). 'Traditional Medicine in Elechi Amadi's The Concubine'.In Mamadou Kandji (ed.), Health and Mental Issues in the Literary Imagination. (103-114). Dakar: Diaspora Academic Press.

[11] Nnamdi-Eruchalu, G.I. (2012). A Study of the Language of Kola Nut in Traditional Igbo Setting, Academic Discourse: An International Journal.2(1). Retrieved July 21, 2018 from: http//www.culturesof westafrica.com/ode-kola-nut/

[12] Parrinder, E.G. (1962). African Traditional Religion (3rd ed). London: Sheldon Press.

[13] The Guinness Encyclopedia of the Living World. (1992). London: Guinness Publishing.

[14] Ugwu, C.O.T. \& Ugwuenye L.U. (2004) African Traditional Religion: AProlegomenon. Lagos: Merit International Publications.

[15] Ukaegbu, F .N. (2002) The Igbos: The African Root of Nations. Ibadan: Heinemann Educational Books (Nig) Plc.

[16] Ụkaegbu, F.Ọ. (2003). Igbo Identity and Personality vis-à-vis Igbo Cultural Symbols. A thesis presented for the doctorate degree.2003 kolanutseries.igbonet.com/jukaegbu/

[17] Umeh, P.O. (1991). Poetry and Social Reality: The Nigerian Experience. Onitsha: Benamax Publishers Limited.

[18] Ofoegbu, F.J. (2003). 'The Kola Nut: As an Igbo Cultural and Social Symbol'. 2003kolanutseries.igbnet. com/jukaegbu/

[19] http://www.vanguardngr.com/2012/04/what-is-this-about-kolanut-in-igboland/

[20] http://azepanig.blogspot.com

[21] http://EzineArticles.com/?expert=Vitus_Ejiogu

[22] http://EzineArticles.com/5498247

[23] http://www.vanguardngr.com/2012/04/what-is-this-about-kolanut-in-igboland/

Citation: Bawa Kammampoal, Suuk Laar. The Kola Nut: Its Symbolic Significance in Chinua Achebe's Things Fall Apart. "International Journal on Studies in English Language and Literature (IJSELL), vol 7, no. 8, 2019, pp. 26-40. doi: http://dx.doi.org/10.20431/2347-3134.0708003.

Copyright: (C) 2019 Authors. This is an open-access article distributed under the terms of the Creative Commons Attribution License, which permits unrestricted use, distribution, and reproduction in any medium, provided the original author and source are credited. 